\title{
遮光処理がメロン果実のエチレン生成と「水浸状果」の発症に及ぼす影響
}

\author{
相川敏之 ${ }^{1} ・$ 西沢 隆 $^{1 *} \cdot$ 伊藤政憲 $^{2} \cdot$ 冨樫政博 $^{2} \cdot$ 山崎紀子 $^{2}$ \\ ${ }^{1}$ 山形大学農学部 997-8555 山形県鶴岡市若葉町 \\ 2 山形県砂丘地農業試験場９98-0112 山形県酒田市浜中
}

\section{Effect of Shading Treatment on Ethylene Production and Water-core in Melon Fruit}

\author{
Toshiyuki Aikawa ${ }^{1}$, Takashi Nishizawa ${ }^{1 *}$, Masanori Ito $^{2}$, Masahiro Togashi ${ }^{2}$ and Noriko Yamazaki ${ }^{2}$ \\ ${ }^{1}$ Faculty of Agriculture, Yamagata University, Tsuruoka, Yamagata 997-8555 \\ ${ }^{2}$ Yamagata Sand Dune Agricultural Experimental Station, Sakata, Yamagata 998-0112
}

\begin{abstract}
'Andesu' netted melon plants (Cucumis melo L.) were grown under shaded or unshaded conditions, and the relationship between the ethylene production and the development of 'water-core' in the fruit was studied. In the pre-ripe stage, ethylene production and fruit softening of the shaded plants were accelerated more than those of the unshaded plants, whereas 'watercore' in the fruit was formed only at and after the ripe stage. Although 'water-core' at the ripe stage was more apparent in the shaded than in the unshaded plants, some of the fruit developed the disorder even in the unshaded plants. In the unshaded plants, however, the number of 'water-cored fruit' did not increase even at the over-ripe stage. In the unshaded plants, both ethylene production and flesh firmness in 'un-disordered fruit' at the over-ripe stage were similar to those in 'water-cored fruit' on shaded plants at the ripe stage. Our results showed that the development of 'water-core' in 'Andesu' netted melon fruit was not due to the high ethylene production at the ripe to over-ripe stages.
\end{abstract}

Key Words : climacteric, flesh firmness, over-ripe, water-soaked symptom キーワード : 過熟, 果肉硬度, クライマクテリック，水浸症状，らるみ果

\section{緒言}

クライマクテリック型のメロン果実 (Cucumis melo L.) では, 成熟期間中に呼吸量およびエチレン生成量が増加し, 果実の成熟を促す様々な生理的变化をもたらす（北村ら, 1974; Seymour ら, 1993). メロン'アンデス’もクライマ クテリック型品種であるが（Nishizawa ら，2000)，収穫期 に「水浸状果」または「らる久果」と呼ばれる生理障害が 発症することがある（Nishizawa ら，2000）。生産現場では 雨天が続いた後に収穫した果実に「水浸状果」の発症が多い (中西ら，1992).「水浸状果」は果肉が半透明状に変化する 生理障害であるが，同時にエチレン生成量やアルコール発 酵の増加（Nishizawa ら，1998, 2000), 糖度や果肉硬度の低 下 (Nishizawa ら，2000), 細胞壁の崩壊を伴う（Du Chatenet ら，2000）。また，一部の品種では，果実成長期にカルシウ ム欠乏処理を行ったり（Bernadac ら，1996; Du Chatenet ら, 2000; Jean-Baptiste ら，1999)，株全体を遮光処理すること で，「水浸状果」を再現することができる（中西ら，1992;

2006 年 5 月 23 日 受付. 2006 年 9 月 11 日 受理.

* Corresponding author. E-mail: nisizawa@tds1.tr.yamagata-u.ac.jp
Nishizawa 5，1998, 2000). カルシウム欠乏処理や遮光処理 は，いずれもメロン果実のエチンン生成量を増加させるこ とから（Nishizawa ら，2000, 2004)，エチレン生成量の増加 が「水浸状果」発症の直接的要因と思わ机る，そこで，本 実験ではメロン‘アンデス’を供試し，遮光処理が果実の エチレン生成量の増加と「水浸状果」発症に及ぼす影響を 調査し，エチレンと「水浸状果」発症との関係を明らかに することを試みた.

\section{材料および方法}

\section{実験 1 遮光処理がメロン果実のエチレン生成量と「水浸 状果」発症に及ぼす影響}

\section{植物材料}

メロンは山形県砂丘地農業試験場の圃場で栽培した. 1998 年 4 月 9 日にガラス温室内にメロン“アンデス’を播 種し，ポット育苗した苗を，5月 6 日に $0.8 \mathrm{~m} \times 2.7 \mathrm{~m}$ の間 隔で 36 株定植し，トンネル早熟栽培を行った. 肥料には, 緩効性肥料 $\left(\mathrm{N}: \mathrm{P}_{2} \mathrm{O}_{5}: \mathrm{K}_{2} \mathrm{O}=10: 17: 13 \mathrm{~kg} \cdot 10 \mathrm{a}^{-1}\right)$ ，苦土 石灰 $\left(60 \mathrm{~kg} \cdot 10 \mathrm{a}^{-1}\right)$ ，苦土重焼燐 $\left(20 \mathrm{~kg} \cdot 10 \mathrm{a}^{-1}\right)$ を全量 基肥として施与した，整枝法は慣行の子づる 2 本仕立て栽 培とし, 子づるの第 $11 〜 15$ 節に 2 果 (1 株あたり 4 果) 着 
果させた. 半数の株は, 厚さ $0.075 \mathrm{~mm}$ のビニルトンネル 内で栽培し (無遮光区), 残り半数は着果後 $35 \sim 54$ 日 (19 日間）にビニルトンネル全体を遮光率 70\%のネットで覆っ た (遮光区). 遮光資材の有無でビニルトンネル内の気温は 変化しなかった（中西ら，1992）。果実は着果後 35 日に 6 果収穫し, その後 40, 45 (果実肥大期)，50 (収穫適期）抒 よび 55 日 (過熟期) に無遮光区拈よび遮光区から 6 果ずつ 収穫した。

\section{エチレン生成量の測定}

収穫した果実の新鮮重を測定し, 約 $5 \mathrm{~L}$ のデシケーター 内に密封し, $20^{\circ} \mathrm{C}$ で 1 時間放置した後, デシケーター内の 気体 $1 \mathrm{~mL}$ をシリンジで抜き取り，活性アルミナカラム拉 よび水素炎イオン化検出器を備えたガスクロマトグラフ （163 型，日立）に注入し，エチレン濃度を測定した。 サン プルの注入は 2 回行い, 平均值を果実のエチレン生成量と して $\mu \mathrm{L} \cdot \mathrm{kg}^{-1} ・ \mathrm{~h}^{-1}$ で表した. エチレン生成量の計算のた めの標準として 1 ppm のエチレンガスを同様に注入し，測 定した.

\section{水浸症状の評価}

エチレン濃度を測定した果実を縦方向に二分割し，切断 面に水浸症状が認められた果実は, 水浸症状の最大幅 $(\mathrm{cm})$ を測定した（Nishizawa ら，1998）。

\section{果肉硬度の測定}

縦断した果実切片の赤道面における中壁部中央 2 ヶ所の 果肉硬度を, 直径 $5 \mathrm{~mm}$ の円柱プランジャーを備えたレオ メーター（CR-1-10K，サン科学）で測定した（Nishizawa ら, 2004).

\section{実験 2 「水浸状果」発症時におけるエチレン生成量と果肉 硬度の比較}

1997，1998，2000 および 2002 年に, 実験 1 と同様に栽 培したメロン“アンデス’を供試した，遮光区は着果後 35

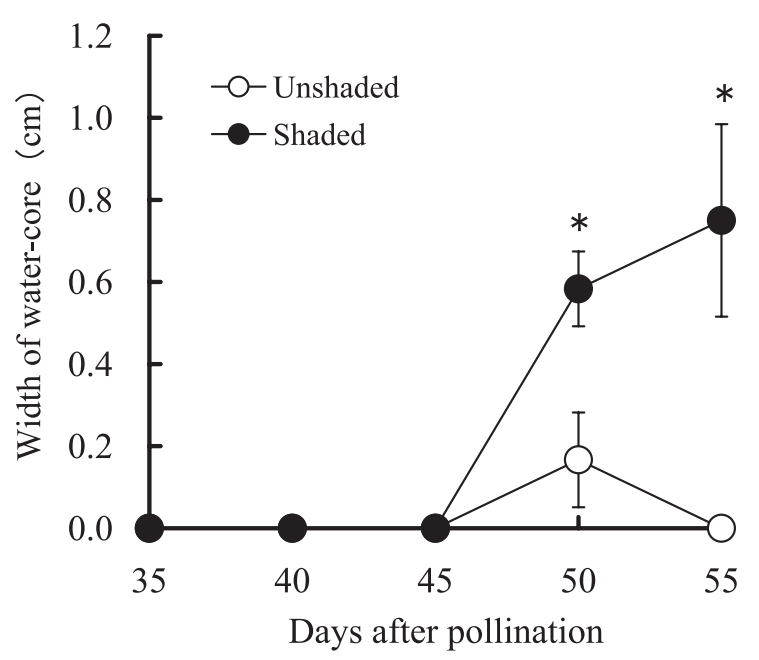

Fig. 1 Effect of shading treatment on the width of 'water-core' in the flesh of 'Andesu' melon fruit in 1998. Each point represents the mean $\pm \mathrm{SE}(\mathrm{n}=6)$. * Significant at $P<0.05$, using student's $t$-test.
〜 50 日まで，ビニルトンネル全体を遮光率 65 ～80\%の ネットで覆った. 水浸症状が初めて認められる収穫適期 （着果後 49 日）に, 無遮光区および遮光区の果実を収穫し, さらに過熟期（着果後 55 日）に, 無遮光区の果実のみを収 穫した (各 $4 \sim 10$ 果). 収穫した果実は, 実験 1 に従って エチレン生成量, 水浸症状の程度拈よび果肉硬度を測定し た. 結果は 4 年間の平均值として表した。

\section{結 果}

\section{実験 1 遮光処理がメロン果実のエチレン生成量と「水浸} 状果」発症に及ぼす影響

無遮光区，遮光区とも，着果後 45 日以前には「水浸状 果」は発症しなかった (第 1 図). 着果後 50 日に打ける水 浸症状は，無遮光区では $0.17 \mathrm{~cm}$ であったが，遮光区では $0.58 \mathrm{~cm}$ と, 無遮光区と比べ有意に大きくなった. また, こ のよらな有意な処理間の差は着果後 55 日でも認められた.

着果後 $35 \sim 40$ 日に打けるエチレン生成量は, 遮光区, 無遮光区とも約 $0.17 \mu \mathrm{L} \cdot \mathrm{kg}^{-1} \cdot \mathrm{h}^{-1}$ で一定していたが, 着 果後 45 日以降になると遮光区, 無遮光区とも増加し, 着果 後 50 日ではそれぞれ 2.4 抢よび $1.3 \mu \mathrm{L} \cdot \mathrm{kg}^{-1} \cdot \mathrm{h}^{-1}$ と, 遮光 区のエチレン生成量が無遮光区より有意に高くなった（第 2 図)。着果後 55 日では両区ともエチレン生成量はさらに 増加したが，処理間に有意差はなかった。

果肉硬度はメロン果実の成熟に伴い低下したが，着果後 50 拈よび 55 日には遮光区の果肉硬度 $(0.13 \sim 0.16 \mathrm{~kg})$ が, 無遮光区 $(0.24 \sim 0.23 \mathrm{~kg})$ より有意に低くなった (第 3 図).

実験 2 「水浸状果」発症時におけるエチレン生成量と果肉 硬度の比較

収穫適期の果実では, 無遮光区の $34.6 \%$ が「水浸状果」 となり，その大きさは $0.64 \mathrm{~cm}$ であった（第 1 表）。一方， 遮光区では $88.5 \%$ が「水浸状果」となり, その大きさは

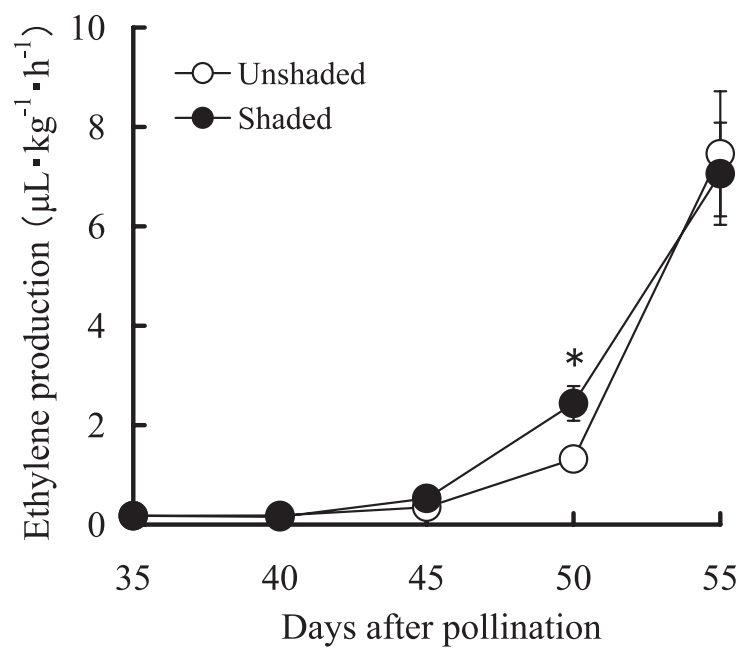

Fig. 2 Effect of shading treatment on the ethylene production of 'Andesu' melon fruit in 1998. Each point represents the mean $\pm \mathrm{SE}(\mathrm{n}=6)$. * Significant at $P<0.05$, using student's $t$-test. 


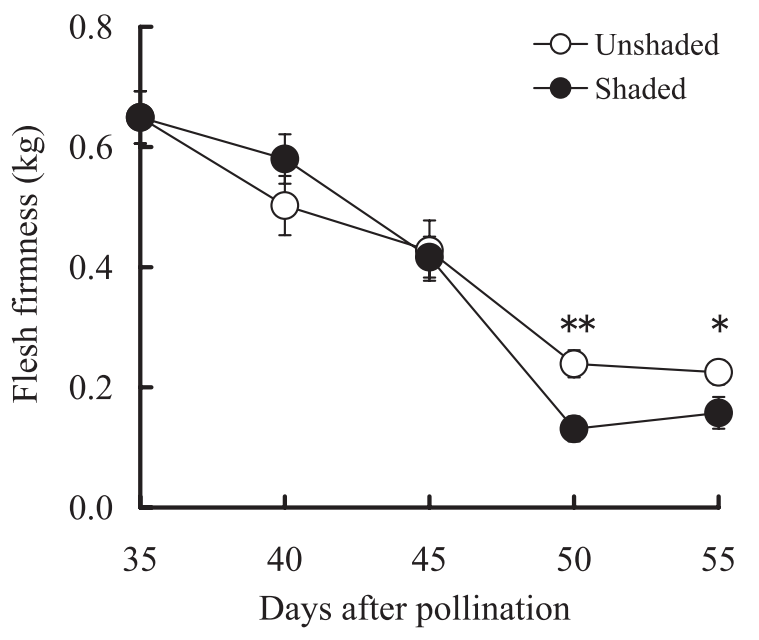

Fig. 3 Effect of shading treatment on the flesh firmness of 'Andesu' melon fruit in 1998. Each point represents the mean $\pm \mathrm{SE}(\mathrm{n}=6){ }^{*}, * *$ Significant at $P<0.05$ and 0.01 , respectively, using student's $t$-test.

Table 1 Effect of shading and fruit maturation on incidence and width of 'water-core' in 'Andesu' melon fruits.

\begin{tabular}{lcc}
\hline \hline \multirow{2}{*}{ Treatment } & \multicolumn{2}{c}{ Water-core } \\
\cline { 2 - 3 } & Incidence $(\%)^{\mathrm{z}}$ & Width $(\mathrm{cm})^{\mathrm{y}}$ \\
\hline Ripe & $0.64 \mathrm{~b}^{\mathrm{x}}$ \\
Unshaded & 34.6 & $0.93 \mathrm{ab}$ \\
$\quad \begin{array}{l}\text { Shaded } \\
\text { Over-ripe } \\
\text { Unshaded }\end{array}$ & $1.33 \mathrm{a}$ \\
\hline z 'Water-cored' fruits/('Normal' fruits + 'Water-cored' fruits $) \times 100$ \\
(n = 26). Data show the mean of four years. \\
${ }^{\mathrm{y}}$ Average of 'water-cored' fruits ( $\left.\mathrm{n}=8-23\right)$. Data show the mean \\
of four years. \\
${ }^{\mathrm{x}}$ Different characters represent significant at $P<0.05$, using the \\
Tukey-Kramer method.
\end{tabular}

$0.93 \mathrm{~cm}$ であった，過熟期の無遮光区では，「水浸状果」の 発症率 $(30.8 \%)$ は収穫適期の遮光区核ど高くならなかっ たが，発症した水浸症状の大きさ $(1.33 \mathrm{~cm})$ は収穫適期の 遮光区に比べてやや大きかった.

遮光処理の有無は，果重に有意差をもたらさなかった (ともに約 $1.6 \mathrm{~kg}$, データ未掲載).収檴適期の無遮光区で は,「水浸状果」が発症した果実の果肉硬度 $(0.21 \mathrm{~kg})$ は, 同症状が発症しなかった果実（「正常果」，0.42 kg）の $1 / 2$ と有意に低下した，同様の傾向は遮光区や過熟期でもみら れたが，両者の間に有意差は認められなかった（第4図).

収穫適期の無遮光区で「水浸状果」が発症した果実の工 チレン生成量 $\left(4.2 \mu \mathrm{L} \cdot \mathrm{kg}^{-1} ・ \mathrm{~h}^{-1}\right)$ は, 「正常果」 $(1.7 \mu \mathrm{L}$ ・ $\mathrm{kg}^{-1} \cdot \mathrm{h}^{-1}$ ) の 2 倍以上に達した (第 5 図). 同様の傾向は遮 光区でも認められ,「水浸状果」が発症した果実のエチレン 生成量 $\left(6.1 \mu \mathrm{L} \cdot \mathrm{kg}^{-1} \cdot \mathrm{h}^{-1}\right)$ は, 遮光区の「正常果」 $(4.5 \mu \mathrm{L} \cdot$ $\left.\mathrm{kg}^{-1} \cdot \mathrm{h}^{-1}\right)$ より高くなったが，両者の間に有意差は認めら

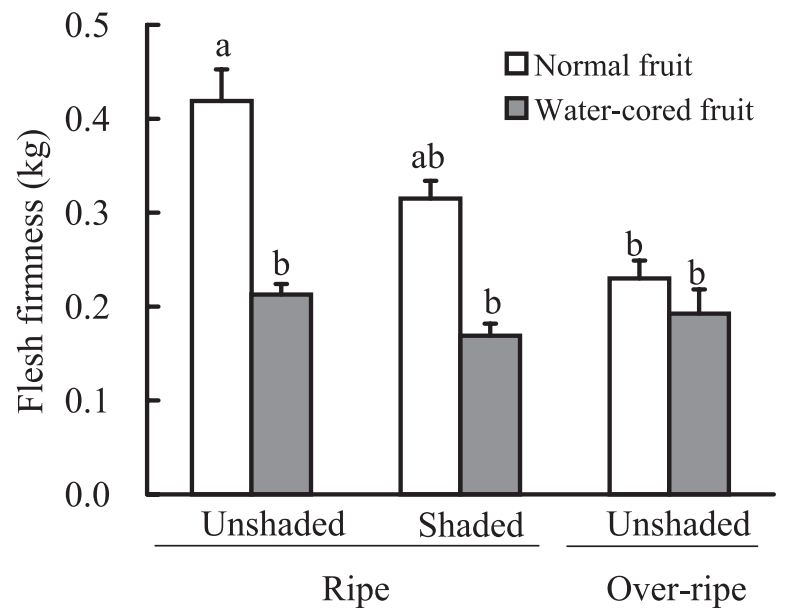

Fig. 4 Comparison of the flesh firmness between 'water-cored' and 'normal' fruits. Each point represents the mean $\pm \mathrm{SE}$ $(n=3-23)$. Data show the mean of four years. Different character represents significant at $P<0.05$, using the TukeyKramer method.

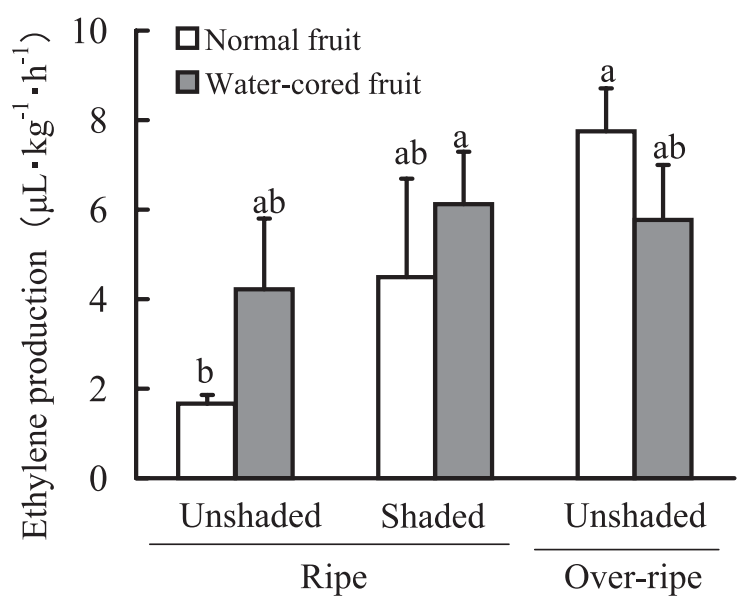

Fig. 5 Comparison of the ethylene production between 'watercored' and 'normal' fruits. Each point represents the mean \pm SE $(n=3-23)$. Data show the mean of four years. Different character represents significant at $P<0.05$, using the Tukey-Kramer method.

れなかった．過熟期の「正常果」（7.8 $\left.\mu \mathrm{L} \cdot \mathrm{kg}^{-1} \cdot \mathrm{h}^{-1}\right)$ では, 収穫適期の「正常果」より有意にエチレン生成量が高くなつ たものの,「水浸状果」 $\left(5.8 \mu \mathrm{L} \cdot \mathrm{kg}^{-1} ・ \mathrm{~h}^{-1}\right)$ との間に有意 差は認められなかった。

\section{考察}

遮光処理はメロン果実に「水浸状果」を発症させる有効な 手法であり, 遮光程度が強い注ど「水浸状果」の発症が多く なる（中西ら，1992）。本実験では，一部の果実は遮光処理 を行わなくとも「水浸状果」が発症したが (第 1 表), 遮光 処理は「水浸状果」を発症させる重要な環境要因である. 本実験では, 4 年間の調査で得られたデータからメロン 
のエチレン生成量と「水浸状果」との関係を検証した。 そ の結果, 「水浸状果」は着果後 35 日以降の果実肥大後期に 株全体を遮光処理することで, 収穫適期に相当する着果後 50 日前後に高い割合で発症し(第 1 表, 第 1 図), そ饥以 前には発症しなかった（第1図）。したがって，メロンの 「水浸状果」は果実の成熟期に限定して発症する生理障害 であるが，その発症要因は果実肥大期の環境要因に強く 影響されることが示唆された。 また，無遮光区であっても 收穫適期には $34.6 \%$ の果実に「水浸状果」が発症したが (第 1 表), これは山形県庄内地域は果実肥大期が梅雨期に 相当することから, 梅雨による日射量不足などの環境要因 の影響を受けた結果と考光られる。

Valantin-Morison ら（2006）は，1株当たりの着果数を増 加させた場合, メロン果実同士で同化産物の競合が起こり, 果実肥大が抑制されることで「水浸状果」が発症すると述 べている. 本実験では, 遮光処理を行っても果重は無遮光 区と変わらなかったが（ともに約 $1.6 \mathrm{~kg}$ )，これは果実肥大 速度が緩やかになった着果後 35 日以降に短期間の遮光処理 を扔こなったことと，果実内部への水の流入が相対的に遮 光区の果実で多かったことが原因と考兄られる (Nishizawa ら，2000）。遮光処理を行うと無遮光区に比べ果実の糖度, 特にスクロース濃度が大きく低下寸ることから（Nishizawa ら，1998，2000），果実に転流する同化産物の減少が「水浸 状果」の直接的要因として作用している可能性がある (Valantin-Morison ら，2006). しかし，中西ら（1992）によ ると, メロン“アンデス’ に执いて無遮光栽培で発症した 「水浸状果」の糖度は, 「正常果」と有意な差はない。した がって, 糖度の低下は「水浸状果」の直接的要因ではない と考光られる。

一方, メロンの「水浸状果」は, 果実発育期に日射量を 抑制することによって誘起される早熟が発症の直接的要 因と思われる（Nishizawa ら，1998）. 本実験の遮光区でも， 收穫適期（着果後 50 日）に急激に果肉硬度が低下したこと (第 3 図), また，收穫適期の無遮光区であっても「水浸状 果」が発症した果実の方が「正常果」より果肉硬度が有意 に低下したことは (第 4 図), 果実の早熟が「水浸状果」の 一因であることを示唆する。しかし, 過熟期では, 「正常 果」であっても收穫適期で「水浸状果」が発症した果実と 同程度に果肉硬度が低下したことから (第 4 図), 收檴適期 に打社果肉硬度の低下は, 必ずしも「水浸状果」の直接 的要因ではないと考觉られる。

本実験で，果肉飞水浸症状が認めら孔た着果後 50 日 (収穫適期) は, 無遮光区打上び遮光区ともエチレン生成量 が急増し, 特に遮光区のエチンン生成量は無遮光区に比べ て有意に高くなった（第 2 図）。しかし，收穫適期の時点で 遮光区の「水浸状果」と「正常果」のエチレン生成量を比 較すると，両者の間に有意差は認められなかった（第 5 図). さらに, 過熟期では, 「正常果」のエチレン生成量は「水浸状 果」と有意差が認められなかったにもかかわらず(第 5 図),
「水浸状果」の発症率は収穫適期の無遮光区に比べ増加し なかったことから (第 1 表), 遮光処理によって收穫適期に 増加したエチレン生成量や過熟に伴って増加したエチレン 生成量が,「水浸状果」発症の直接的要因になっているとは 言えない。

Valantin-Morison ら（2006）は「水浸状果」が発症したメ ロン果実と「正常果」との間のエチレン生成量には差がな いと述べている，また，Ca 欠乏に伴い生じるメロンの「水 浸状果」では, クライマクテリックに拈けるエチレン生成 量の増加前にエチレン作用阻害剂である1-メチルシクロプ ロペン（1-MCP）を処理した場合でも，未処理の果実と同 時期に「水浸状果」が発症することから（Du Chatenetら， 2000), 「水浸状果」の発症には収穫期の高濃度のエチレン は必要ないことが示唆される。

メロン果実は成熟初期であってもエチレンに反応し, 成 熟初期に生じる低濃度のエチレン生成は，その後の成熟に よって生じるテクスチャーなどの変化に重要な役割を持 つ(Bianco ら, 1977; Pratt ら, 1977; Yamamoto ら, 1995). 本実験に打いて, エチレン生成の増加が始まる着果後 45 日 のエチレン生成量は, 処理間で有意差は認められないもの の, 遮光区 $\left(0.53 \mu \mathrm{L} \cdot \mathrm{kg}^{-1} \cdot \mathrm{h}^{-1}\right)$ の值は無遮光区 $(0.35 \mu \mathrm{L}$ ・ $\mathrm{kg}^{-1} \cdot \mathrm{h}^{-1}$ ) の 1.5 倍に達した (第 2 図). 従って, エチレン が「水浸状果」発症の直接的原因でないにしても, 遮光処 理または日照不足によって生じた成熟初期のエチレン生成 により誘起された果実内部の生理的変化が,「水浸状果」の 発症の直接的要因である可能性がある.

Du Chatenet ら（2000）は，細胞壁の崩壊により拡大した 細胞間隙に，水が流入することで「水浸状果」が発症する と推察した。メロン果実では, $\beta$-ガラクトシダーゼが果肉 硬度の低下に伴う細胞壁成分の分解に重要な役割を持つ (Ranwala ら，1992）。トマト果実では成熟に関連する数種 の $\beta$ - ガラクトシダーゼの mRNA の蓄積が, エチレンによっ て制御される (Moctezuma ら, 2003). 従って, 細胞壁分解 酵素の活性が早期に発現または活性が高まることで細胞壁 のかい離が生じ, 細胞間隙に流入した水によって「水浸状 果」が発症したと思われる。

\section{摘 要}

メロン ‘アンデス’を遮光ないし無遮光条件下で育て, 果 実のエチレン生成量と「水浸状果」発症との関係を調べた.

1. 遮光区では, 収穫適期以前に抢ける果実のエチレン生 成量の増加と果肉の軟化が, 無遮光区より顕著に現孔 たが，「水浸状果」は収穫適期以降での久発症した。

2. 収穫適期に発症する「水浸状果」は, 無遮光区上り遮 光区でより顕著に増加したが, 一部の果実では無遮光 区でも発症した．また，無遮光区では，過熟期になっ て子「水浸状果」の発症率は上昇しなかった.

3. 無遮光区では, 過熟期に㧍ける「正常果」の果肉硬度 やエチレン生成量は, 收穫適期に打汀る遮光区の「水 
浸状果」と同程度の值を示した.

本実験の結果から，メロン“アンデス’果実に打ける「水 浸状果」の発症には，収穫適期以降に認められる高いエチ レン生成は必要なく，遮光処理によって生じた，成熟初期 のエチレン生成の増加が重要な役割を持っていると考えら れた。

謝 辞 本研究の実施にあたり, 多大な御援助を頂いた山 形県砂丘地農業試験場の諸氏に心よりお礼申し上げます。

\section{引用文献}

Bernadac, A., I. Jean-Baptiste, G. Bertoni and P. Morard. 1996. Changes in calcium contents during melon (Cucumis melo L.) fruit development. Sci. Hortic. 66: 181-189.

Bianco, V. V. and H. K. Pratt. 1977. Compositional changes in muskmelons during development and in response to ethylene treatment. J. Amer. Soc. Hort. Sci. 102: 127-133.

Du Chatenet, C., A. Latche, E. Olmosc, B. Ranty, M. Charpenteau, R. Ranjeva, J. C. Pech and A. Graziana. 2000. Spatialresolved analysis of histological and biochemical alterations induced by water-soaking in melon fruit. Physiol. Plant. 110: $248-255$.

Jean-Baptiste, I., P. Morardo and A. Bernadac. 1999. Effect of temporary calcium deficiency on the incidence of a nutritional disorder in melon. Acta Hort. 481: 417-423.

北村利夫. 1974. メロン果実の貯蔵に関する研究. 第 1 報. 追熟中に打ける呼吸量，エチンン生成および揮発性物 質生成の変化と品種間差異. 山形大紀要 (農学). 7:253260

Moctezuma, E., D. L. Smith and K. C. Gross. 2003. Effect of ethylene on mRNA abundance of three $\beta$-galactosidase genes in wild type and mutant tomato fruit. Postharv. Biol. Technol. 28: 207-217.

中西政則・栗田公司・北川 守. 1992. 遮光拈よびかん水
がメロンのらるみ果発生に及ぼす影響. 日砂丘誌. 39: 9-17.

Nishizawa, T., A. Ito, Y. Motomura, M. Ito and M. Togashi. 2000. Changes in fruit quality as influenced by shading of netted melon plants (Cucumis melo L. 'Andesu' and 'Luster'). J. Japan. Soc. Hort. Sci. 69: 563-569.

Nishizawa, T., T. Kobayashi and T. Aikawa. 2004. Effect of calcium supply on the physiology of fruit tissue in 'Andesu' netted melon. J. Hort. Sci. Biotechnol. 79: 500-508.

Nishizawa, T., S. Taira, M. Nakanishi, M. Ito, M. Togashi and Y. Motomura. 1998. Acetaldehyde, ethanol, and carbohydrate concentrations in developing muskmelon fruit (Cucumis melo L. cv. Andesu) are affected by short-term shading. HortScience 33: 992-994.

Pratt, H. K., J. D. Goeschl and F. W. Martin. 1977. Fruit growth and development, ripening, and the role of ethylene in the 'Honey Dew' muskmelon. J. Amer. Soc. Hort. Sci. 102: 203-210.

Ranwala, A. P., C. Suematsu and H. Masuda. 1992. The roll of $\beta$-galactosidases in the modification of cell wall components during muskmelon fruit ripening. Plant Physiol. 100: 1318-1325.

Seymour, G. B. and W. B. McGlasson. 1993. Melons. p. 273 290. In: G. Seymour, J. Taylor and G. Tucker (eds.) Biochemistry of fruit ripening. Chapman \& Hall, London.

Valantin-Morison, M., B. E. Vaissiere, C. Gary and P. Robin. 2006. Source-sink balance affects reproductive development and fruit quality in cantaloupe melon (Cucumis melo L.). J. Hort. Sci. Biotechnol. 81: 105-117.

Yamamoto, M., T. Miki, Y. Ishiki, K. Fujinami, Y. Yanagisawa, H. Nakagawa, N. Ogura, T. Hirabayashi and T. Sato. 1995. The synthesis of ethylene in melon fruit during the early stage of ripening. Plant Cell Physiol. 36: 591-596. 